\title{
Basic processes in reading: On the development of cross-case letter matching without reference to phonology
}

\author{
DAVE RYNARD and DEREK BESNER \\ University of Waterloo, Waterloo, Ontario, Canada
}

\begin{abstract}
We report the case of a youngster who has not learned to name correctly all of the letters of the alphabet, but who nonetheless can do cross-case matching (Posner's name-matching task) of all the letters, entirely without error. This result suggests that the development of cross-case matching abilities in normal subjects may also proceed without reference to a letter identification process based upon a phonological code.
\end{abstract}

A prominent question in the literature concerns how words are recognized. One widely held view is that this process depends upon preliminary letter identification (e.g., Adams, 1979; Allport, 1979; Besner, 1983; Besner, Davelaar, Alcott, \& Parry, 1984; Coltheart, 1981; Henderson, 1982; Johnston, 1981; McClelland, 1976; McClelland \& Rumelhart, 1981; Paap, Newsome, \& Noel, 1984; Saffran, 1980; Well \& Pollatsek, 1981). If this assumption is correct, the question arises as to how a reader knows that different physical forms of a letter (e.g., A and a) signal something common. One view, at least in tasks in which subjects are explicitly asked whether different physical forms share the same label, is that stimulus equivalence is based on the assignment and comparison of name codes (e.g., Posner, 1969, 1970, 1972, 1975; Posner, Boies, Eichelman, \& Taylor, 1969; Posner \& Keele, 1967; Posner, Lewis, \& Conrad, 1972; Posner \& Mitchell, 1967; Posner \& Taylor, 1969). Posner (1978, see pages 39-41) quite explicitly equates name code with a phonetic code; nothing in more recent statements indicates a change in this view (see Posner, 1982).

However, recent evidence from adult patients with an acquired dyslexia (see Coltheart, 1981) and normal adult subjects (Besner, Coltheart, \& Davelaar, 1984; Boles \& Eveland, 1983) suggests that stimulus equivalence can be achieved without recourse to a phonological code. The use of abstract letter identities, and/or visual-visual associations have been suggested as alternative bases for this achievement.

What these experiments do not tell us is whether phonological codes play any role in the development of crosscase letter matching ability. One possibility is that crosscase matching is initially dependent upon learning the association between two or more symbols through assignment of a common name. With practice, a direct link be-

Supported by Grant A0998 from the Natural Sciences and Engineering Research Council of Canada to Derek Besner and an undergraduate summer research fellowship award from NSERC to Dave Rynard. Address reprint requests to Derek Besner, Department of Psychology, University of Waterloo, Waterloo, Ontario N2L 3G1, Canada. tween the visual symbols is forged (or a link to an "abstract letter identity"; see Coltheart, 1981) and the name is no longer necessary. An alternative is that associations between the visual symbols are formed in the absence of learning a common name. Both or either of these possibilities alone may contribute to the development of cross-case matching abilities. A proof for the latter possibility is demonstrable if any reader exists who has not yet learned to correctly assign names to individual letters, but who nevertheless is capable of cross-case letter matching. We report such a case.

\section{METHOD}

\section{Subject}

The subject (P.H.) was a 16-year-old, right-handed male who has acquired only minimal reading ability. His ability to form and understand spontaneous speech appears entirely normal. There is no history or current evidence of any form of neurological impairment (EEG tests in 1978 were normal; no CT scan has ever been carried out). P.H. was first assessed on the WISC-R at 9 years of age and obtained a full-scale IQ of 71 (Verbal IQ = 64; Performance IQ = 85). He was tested again at age 16 and scored 73 on the WISC-R (Verbal IQ $=51$; Performance $\mathrm{IQ}=95$ ). At this time, he performed within the normal range on all performance subtests and below normal on all verbal subtests. P.H. exhibited a somewhat reduced digit span ( 5 forward, 4 backward), which translates into an estimated age score of 6.5 years.

The Wide Range Achievement Test was administered to assess his reading, arithmetic, and spelling abilities. At age 16, he was reading at grade level 1.7, spelling at 1.9, and performing arithmetic at 3.0. His performance on the Doltch Word List was at the primary level. His age score on the Peabody Picture Vocabulary Test was 12.7 years.

These results indicate that P.H. has a severe difficulty in dealing with written language. These difficulties occur in the context of a reduced IQ (verbal) and subnormal vocabulary skills. We note, however, that P. H.'s spoken vocabulary is much better than indicated by his ability to read aloud, and would suggest that his inability to read has held back his development of a more extensive vocabulary. The observed ability to deal with spoken language, coupled with severe difficulties in dealing with printed language in the absence of any neurological abnormalities and emotional problems, is usually taken as justifying the description of developmental dyslexia.

\section{Procedure}

Three separate tests were conducted to assess P.H.'s letter recognition abilities (naming, sounding, and identifying via cross-case matching). In the letter naming and letter sounding tests, P.H. was presented 
Table 1

Percent Correct, Errors, and Reaction Time on Each Task

\begin{tabular}{|c|c|c|c|c|}
\hline \multirow[b]{2}{*}{ Task } & \multirow[b]{2}{*}{ Percent Correct } & \multirow[b]{2}{*}{ Errors* } & \multicolumn{2}{|c|}{ Correct } \\
\hline & & & $\mathbf{R T} \dagger$ & $S E$ \\
\hline Cross-Case Matching & 100 & none & 1,348 & 85 \\
\hline Naming & 69 & 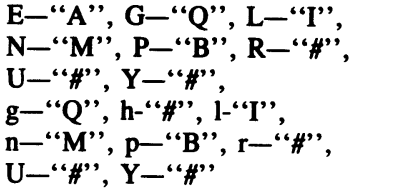 & 1,385 & 113 \\
\hline Sounding & 65 & 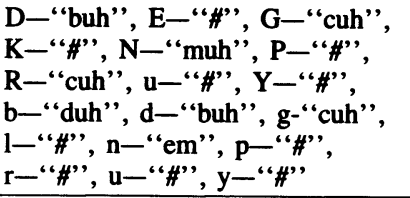 & 1,607 & 155 \\
\hline
\end{tabular}

*\# = "don't know" response. †Reaction times are given in milliseconds.

with the 26 uppercase and 26 lowercase letters of the alphabet. He was required to name the letter in the naming task and to articulate the sound in the sounding task. In the cross-case matching task, he was presented with 52 pairs of upper- and lowercase letters. Half consisted of two samename letters in different cases, and the other half consisted of pairs with different names, one in uppercase and one in lowercase. P.H. was asked to tell the experimenter whether the two letters were the same or not (a list of these stimuli is presented in the Appendix).

Testing was carried out with the assistance of an Apple II microcomputer, which displayed stimuli on a remote CRT, timed and collected the responses, and analyzed the data. Each trial began with P.H. fixating on a small cross displayed in the middle of the CRT. When he was ready, P.H. initiated a trial by pressing a button directly in front of him. The cross then disappeared and was replaced with a display that remained on until P.H. made a response. His response (the letter name in the naming task; the sound in the sounding task; a "yes" for same or a "no" for different in the cross-case matching task) tripped a voice key.

\section{RESULTS}

Table 1 presents a summary of P.H.'s naming latency and actual errors made in all three tasks. Practice trials and trials on which an error was committed were discarded from the reaction time calculations. The important point is that P.H. made no errors in the cross-case matching task, despite moderate deficits at both naming and sounding the individual letters.

An additional analysis of the cross-case matching reaction time data is presented in Table 2. The reaction time data is reported as a function of whether or not an error was committed in the letter naming task. This data offers further support for the notion that letter names are not involved in the process of cross-case letter matching, since

Table 2

Cross-Case Matching Reaction Time Data as a Function of Whether or Not Individual Letters Were Correctly Named in the Letter Naming Task

\begin{tabular}{lrr}
\hline & $\begin{array}{c}\text { Correctly } \\
\text { Named }\end{array}$ & $\begin{array}{c}\text { Incorrectly } \\
\text { Named }\end{array}$ \\
\hline$n$ & 32 & 20 \\
Mean ReactionTime* & 1,380 & 1,297 \\
Standard Error & 121 & 78 \\
\hline
\end{tabular}

*Reaction times are given in milliseconds. letters that are incorrectly named in the letter naming task, or whose names are not known, are correctly classified in the cross-case matching task no more slowly than are letters whose names are known.

\section{DISCUSSION}

The results of these tests are straightforward. Cross-case matching can be carried out entirely without error in the absence of a demonstrated ability to attach the correct names or sounds to some of the individual letters. Some form of orthographic code (i.e., an abstract letter identity; see Allport, 1979; Coltheart, 1981; Evett \& Humphreys, 1981 ) or a direct visual-visual association provides a sufficient basis for cross-case matching.

These results demonstrate that knowledge of the letter name is not a necessary condition for development of the ability to cross-case match. The nature of the representation(s) recruited by normal young readers remains to be determined.

\section{REFERENCES}

Adams, M. J. (1979). Models of word recognition. Cognitive Psychology, 11, 133-176.

ALLPORT, D. A. (1979). Word recognition in reading: A tutorial review. In P. A. Kolers, H. Bouma, \& M. Wrolstad (Eds.), Processing of visible language (Vol. 1). New York: Plenum Press.

BESNER, D. (1983). Basic decoding components in reading: Two dissociable feature extraction processes. Canadian Journal of Psychology, 37, 429-438.

Besner, D., Coltheart, M., \& DavelaAr, E. (1984). Basic processes in reading: Computation of abstract letter identities. Canadian Journal of Psychology, 38, 126-134.

Besner, D., DavelaAr, E., Alcott, D., \& PARry, P. (1984). Wholistic reading of alphabetic print: Evidence from the FBI and the FDM. In L. Henderson (Ed.), Orthographies and reading: Perspectives from cognitive psychology, neuropsychology and linguistics. Hillsdale, NJ: Erlbaum.

Boles, D. B., \& Eveland, D. C. (1983). Visual and phonetic codes and the process of generation in letter matching. Journal of Experimental Psychology: Human Perception \& Performance, 9, 657-674.

ColthearT, M. (1981). Disorders of reading and their implications for models of normal reading. Visible Language, 15, 245-286.

EvetT, L. J., \& HumpHREYs, G. W. (1981). The use of abstract graphemic information in lexical access. Quarterly Journal of Experimental Psychology, 33A, 325-350.

HENDERSON, L. (1982). Orthography and word recognition in reading. New York: Academic Press.

JoHNSTON, J. C. (1981). Understanding word perception: Clues from studying the word superiority effect. In O. J. L. Tzeng \& H. Singer 
(Eds.), Perception of print: Reading research in experimental psychology. Hillsdale, NJ: Erlbaum.

McClelland, J. L. (1976). Preliminary letter identification in the perception of words and nonwords. Journal of Experimental Psychology: Human Perception \& Performance, 2, 80-91.

McClelland, J. L., \& RumelharT, D. E. (1981). An interactive activation model of context effects in letter perception: Part I. An account of basic findings. Psychological Review, 88, 375-407.

PaAP, K. R., Newsome, S. L., \& Noel, R. W. (1984). Word shapes in poor shape for the race to the lexicon. Journal of Experimental Psychology: Human Perception \& Performance, 10, 413-428.

PosNER, M. I. (1969). Abstraction and the process of recognition. In G. Bower \& J. T. Spence (Eds.), Psychology of learning and motivation (Vol. 3). New York: Academic Press.

Posner, M. I. (1970). On the relationship between letter names and superordinate categories. Quarterly Journal of Experimental Psychology, 22, 279-287.

Posner, M. I. (1972). Coordination of internal codes. In W. G. Chase (Ed.), Visual information processing. New York: Academic Press.

PosNeR, M. I. (1975). The temporal course of pattern recognition in the human brain. In C. F. Inbar (Ed.), Signal analysis and pattern recognition in bio-medical engineering. Tel Aviv: Israel Universities Press.

Posner, M. I. (1978). Chronometric explorations of mind. Hillsdale, NJ: Erlbaum.

Posner, M. I. (1982, November 29). Current Contents, p. 18.

Posner, M. I., Boies, S. J., Eichelman, W. H., \& TAylor, R. L. (1969). Retention of visual and name codes of single letters. Journal of Experimental Psychology, 79, 1-16.

Posner, M. I., \& KeELe, S. W. (1967). Decay of information from a single letter. Science, 158, 137-139.

Posner, M. I., LeWIS, J., \& ConRad, C. (1972). Component processes in reading: A performance analysis. In J. Kavanagh \& I. Mattingly (Eds.), Language by eye and by ear. Cambridge, MA: MIT Press.

PosNer, M. I., \& Mitchell, R. F. (1967). Chronometric analysis of classification. Psychological Review, 74, 392-409.

PoSNER, M. I., \& TAYLOR, R. L. (1969). Subtractive method applied to separation of visual and name components of multiletter arrays. Acta Psychologia, 30, 104-114.

SafFran, E. M. (1980). Reading in deep dyslexia is not ideographic. Neuropsychologia, 18, 219-223.

Well, A. D., \& Pollatsek, A. (1981). Word processing in reading: A commentary on the papers. Visible Language, 15(3, Part 2).
APPENDIX

Cross-Case Matching Stimulus Set

\begin{tabular}{|c|c|}
\hline Same & Different \\
\hline$A-a$ & $A-c$ \\
\hline$B-b$ & $B-d$ \\
\hline $\mathrm{C}-\mathrm{c}$ & $\mathrm{C}-\mathrm{r}$ \\
\hline$D-d$ & D-b \\
\hline $\mathrm{E}-\mathrm{e}$ & $E-i$ \\
\hline$F-f$ & $F-p$ \\
\hline $\mathrm{G}-\mathrm{g}$ & $G-b$ \\
\hline $\mathbf{H}-\mathrm{h}$ & $\mathrm{H}-\mathrm{f}$ \\
\hline $\mathrm{I}-\mathrm{i}$ & $\mathrm{I}-\mathrm{e}$ \\
\hline $\mathrm{J}-\mathrm{j}$ & $\mathbf{J}-\mathbf{g}$ \\
\hline $\mathrm{K}-\mathrm{k}$ & $\mathrm{K}-\mathrm{h}$ \\
\hline $\mathrm{L}-\mathrm{l}$ & $\mathbf{L}-\mathbf{s}$ \\
\hline $\mathbf{M}-\mathbf{m}$ & $\mathbf{M}-\mathbf{t}$ \\
\hline $\mathrm{N}-\mathrm{n}$ & $\mathrm{N}-\mathrm{x}$ \\
\hline $\mathrm{O}-\mathrm{o}$ & $\mathrm{O}-\mathrm{u}$ \\
\hline$P-p$ & $P-q$ \\
\hline$Q-q$ & $Q-p$ \\
\hline$R-r$ & $\mathbf{R}-\mathbf{1}$ \\
\hline$S-S$ & $S-y$ \\
\hline$T-t$ & $T-j$ \\
\hline $\mathrm{U}-\mathbf{u}$ & $\mathrm{U}-\mathrm{o}$ \\
\hline$V-v$ & $\mathrm{~V}-\mathrm{k}$ \\
\hline $\mathbf{W}-\mathbf{w}$ & $\mathrm{W}-\mathrm{m}$ \\
\hline$X-x$ & $X-v$ \\
\hline$Y-y$ & $Y-z$ \\
\hline $\mathrm{z}-\mathrm{z}$ & $Z-n$ \\
\hline
\end{tabular}

(Manuscript received for publication March 9, 1987.) 